\title{
TESTANDO A EFICIÊNCIA DAS AULAS PRÁTICAS NO APRENDIZADO DE BIOLOGIA, A PARTIR DE MATERIAIS DE BAIXO CUSTO
}

\author{
TESTING THE EFFICIENCY OF PRACTICAL CLASSES IN LEARNING \\ BIOLOGY, USING LOW-COST MATERIALS
}
LA EFICIENCIA DE LAS CLASES PRÁCTICAS EN EL APRENDIZAJE DE BIOLOGÍA, UTILIZANDO MATERIALES DE BAJO COSTO)

\section{Susane Silva Sartori ${ }^{1 *}$ (D) 9}

\author{
Katiane Mara Ferreira ${ }^{2 * *}$ (ID) (9)
}

\begin{abstract}
RESUMO
Um dos maiores desafios dos professores de Biologia ao lecionar no ensino médio, está na adequação de recursos didáticos alternativos no processo de ensino, de modo que facilite a mediação e a compreensão do conteúdo abordado. As aulas práticas como método de ensino é uma ferramenta importante e uma ponte de interação entre os conhecimentos científicos e empíricos. Pensando na escassez dos recursos didáticos enfrentada pelos professores, principalmente nas escolas publicas, o presente estudo teve como objetivo testar a eficiência de aulas práticas de biologia para o ensino médio, utilizando materiais de baixo custo. Foram selecionadas aulas práticas para os três anos do ensino médio. Para cada prática selecionada, os participantes tiveram uma aula teórica/expositiva prévia, com abordagem voltada ao assunto envolvendo a aula prática. Após a aula teórica, os participantes responderam um questionário de múltipla escolha referente o assunto abordado durante a aula teórica. Na sequencia foi realizada a aula prática correspondente à aula teórica ministrada. Após a aula prática, o mesmo questionário foi aplicado novamente. Análises com o uso de teste t-pareado e médias gerais de acerto foram realizadas para avaliar a eficácia da aula prática no processo de ensinoaprendizagem. Nossos resultados demonstram que, após as aulas práticas houve aumento significativo na aprendizagem dos discentes, evidenciando que a aplicação das mesmas, contribuiu de maneira eficiente, não só com o aprendizado do tema abordado na aula, mas também em outros temas relacionados.
\end{abstract}

Palavras-chave:Práticas. Metodologias ativas. Aprendizagem. Biologia.

\begin{abstract}
One of the biggest challenges for Biology teachers when teaching in high school is the adequacy of alternative didactic resources in the teaching process, in a way that facilitates the mediation and understanding of the content covered. Practical classes as a teaching method can be an important tool and an interaction bridge between scientific and empirical knowledge. Considering the scarcity of teaching resources faced by teachers, especially in public schools, this study aimed to test the efficiency of practical biology classes for high school, using low-cost materials. Practical classes were

\footnotetext{
${ }^{*}$ Mestre pelo programa ProfBio (UFMT), atualmente é professora na rede estadual de Mato grosso.

*** Pós-Doutorado pelo Museu de Zoologia da Universidade de São Paulo. Atualmente é Professora Associada II do Departamento de Biologia e Zoologia da Universidade Federal de Mato Grosso (UFMT-Cuiabá). Cuiabá, Mato Grosso. CEP:78060-900. E-mail: kmferreira@gmail.com
} 
selected for the three years of high school. For each selected practice, participants had a previous theoretical/expository class, with a focused approach to the subject involving the practical class. After the lecture, participants answered a multiple-choice questionnaire regarding the subject covered during the lecture. Next, the practical class corresponding to the theoretical class taught was held. After the practical class, the same questionnaire was applied again. Analyzes with the use of paired t-test and general correctness means were carried out to evaluate the effectiveness of the practical class in the teaching-learning process. Our results show that after the practical classes there was a significant increase in student learning, showing that their application efficiently contributed not only to the learning of the topic addressed in class, but also to other related topics.

Keywords: Practices. Active methodologies. Learning. Biology.

\section{RESUMEN}

Uno de los mayores retos de los profesores de biología a la hora de impartir clases en la secundaria es la adecuación de recursos alternativos en el proceso docente, para facilitar la mediación y la comprensión de los contenidos abordados. Las clases prácticas como método de enseñanza pueden ser una herramienta importante y un puente de interacción entre el conocimiento científico y empírico. Pensando en la escasez de recursos didácticos que enfrentan los docentes, especialmente en las escuelas públicas, el presente estudio tuvo como objetivo poner a prueba la eficiencia de las clases prácticas de biología para la escuela secundaria, utilizando materiales de bajo costo. Las clases prácticas fueron seleccionadas para los tres años finales de la secundaria. Para cada práctica seleccionada, los participantes tuvieron una clase teórica/expositiva previa, con un enfoque centrado en el tema relacionado con la clase práctica. Después de la clase teórica, los participantes respondieron un cuestionario de opción múltiple sobre el tema abordado durante la clase teórica. A continuación, se llevó a cabo la clase práctica correspondiente a la clase teórica impartida. Después de la clase práctica, se aplicó de nuevo el mismo cuestionario. Análisis usando una prueba de T emparejada y medias generales fueron realizados para evaluar la eficacia de la clase práctica en el proceso de enseñanzaaprendizaje. Nuestros resultados muestran que, después de las clases prácticas, hubo un aumento significativo en el aprendizaje de los estudiantes, evidenciando que su aplicación contribuyó de manera eficiente, no sólo con el aprendizaje del tema abordado en la clase, sino también en otros temas relacionados.

Palabras clave: Prácticas. Metodologías activas. Aprendizaje. Biología.

\section{INTRODUÇÃO}

Um dos maiores desafios dos professores de Biologia ao lecionar no ensino médio, está na adequação de recursos didáticos alternativos ao processo de ensino, de modo que facilite a mediação e a compreensão do conteúdo abordado. A ausência de recursos didáticos e dificuldades em elaborar estratégias de baixo custo para aprimorar o ensino em Biologia é uma problemática a se pensar e se resolver (LIMA, 2017).

As discussões mais difundidas quando o assunto é o ensino de Biologia diz respeito à escolha dos métodos didáticos empregados para abordar os temas que envolvem a disciplina. Dentre as metodologias possíveis de serem empregadas, a aula expositiva teórica aparece entre as metodologias mais utilizadas durante o processo de ensino e aprendizagem em Biologia. Sua escolha é justificada pela facilidade de aplicação, já que para aulas práticas e 
outros métodos alternativos exigem recursos e tempo (LIMA; GARCIA, 2011).

As instituições de ensino estão passando por um momento onde há a real necessidade do planejamento de novos métodos pedagógicos, com custo mais acessível e de modo que se aperfeiçoe o ensino e a aprendizagem, motivando professores e participantes a buscarem pela eficiência nos estudos (MITRE, 2008). É da responsabilidade dos docentes proporcionar aos seus discentes experiências de aprendizagem eficazes, combatendo as dificuldades mais comuns e atualizando, tanto quanto possível, os instrumentos pedagógicos que utilizam (FIOLHAIS \& TRINDADE, 2003). A função do professor é propiciar aos discentes a construção de aprendizagens significativas. A maneira como são propostas as situações de ensino e aprendizagem são decisivas para que a aprendizagem significativa se concretize (BARBOSA; CAMPOS; VALENTIM, 2011). Dentro deste contexto, observa-se a grande necessidade da elaboração de novas estratégias de ensino em Biologia que seja de baixo custo, já que o modo de ensino tradicional, palestrada, está ultrapassado (LUZ; LIMA; AMORIM, 2018).

As mudanças e transformações dos agentes tornam a transmissão de conhecimento um processo bastante dinâmico, que requer acompanhamento permanente e a busca também permanente de novas práticas, que visem a quebra de paradigmas (BARBOSA \& MOURA, 2013). Além de se obter ferramentas eficazes de ensino para se ter sucesso na aprendizagem, ainda há a necessidade de se educar dentro das bases científicas. De acordo com Rocha \& Soares (2005), para que um país se desenvolva de forma harmoniosa, seja sustentável e esteja dentro de um mundo globalizado, sua população deve ter um nível de alfabetização científica, consideravelmente bom.

Uma prática pedagógica alternativa ao ensino tradicional que tem ganhado destaque no meio educacional é a metodologia ativa. Ao invés do ensino baseado na transmissão de informação, onde o professor atua como protagonista, na metodologia ativa, o participante adota uma postura mais ativa, participativa, na qual ele elabora solução para problemáticas, cria e desenvolve projetos e, com isso, se forma a possibilidade da criação e não apenas a reprodução do conhecimento (VALENTE, 2017; SCHNEIDER, 2013). Dentro da metodologia ativa, não cabe ao professor, a transmissão de falas prontas e conceituais e sim, a organização e mediação de atividades previamente organizadas e sequenciadas que partam de problemáticas que os alunos devem resolver, individualmente ou em grupos (SUHR, 2016; SANTIAGO \& CARVALHO, 2018). Dentro deste contexto, as aulas práticas são fundamentais para demonstração e mediação do conhecimento, pois além de chamar a atenção 
dos discentes pela dinâmica da aula em si, os temas trabalhados tornam-se mais visíveis e palpáveis. Assim, o objetivo deste trabalho foi avaliar a eficiência de aulas práticas de Biologia no ensino médio, readequando o percurso metodológico para que fossem utilizados materiais de baixo custo.

\section{METODOLOGIA}

\subsection{Seleção das aulas práticas}

As aulas práticas escolhidas para realização do presente estudo, se pautou na observação pessoal da primeira autora (SSS), no qual levou em consideração o interesse e as dificuldades encontradas pelos discentes em determinados temas do curso de Biologia para o ensino Médio.

A pesquisa foi desenvolvida nas turmas de primeiro, segundo e terceiro ano do ensino médio, como descrito abaixo:

\subsubsection{Primeiro ano do ensino médio:}

Extração do DNA da banana - a prática visa a extração, visualização e confirmação da existência do DNA da banana.

\subsubsection{Segundo ano do ensino médio:}

Fermentação por microrganismos - a prática visa a interdisciplinarização da microbiologia, bioquímica, química e física, através dos processos de fermentação láctica e alcoólica, forma comum de obtenção de benefícios por meio da utilização de organismos vivos.

Montagem de modelos anatómicos com materiais reaproveitados - Esta prática tem como objetivo identificar as partes que compõem o corpo humano. Foram estudados alguns aspectos relacionados com a estrutura e o funcionamento do corpo humano em um modelo didático, desde os órgãos até os sistemas que o compõem o corpo.

\subsubsection{Terceiro ano do ensino médio:}

Sistema $\mathrm{ABO}$ e fator $\mathrm{Rh}$ - a prática melhora a visualização do aluno aos processos imunológicos que regem o sistema $\mathrm{ABO}$ e os fatores $\mathrm{Rh}$. 
Evolução biológica: Seleção natural em tentilhões - a prática visa entender como o ambiente atua de diferentes formas sobre os organismos (salinidade, $\mathrm{pH}$, temperatura, umidade, doenças, parasitismo, predação). Esta atuação do ambiente é a seleção natural. Aqueles organismos que apresentam características que permitem melhor adaptação ao ambiente possuem maiores chances de chegar à fase adulta e deixar descendentes.

\subsection{Local de Estudo e Avaliação das Práticas}

O presente estudo foi realizado em uma escola pública do município de Jaciara-MT, no qual a primeira autora (SSS) ministra a disciplina de Biologia. Para cada prática selecionada, os participantes tiveram uma aula teórica/expositiva prévia, com abordagem voltada ao assunto envolvendo a aula prática. Após a aula teórica, os participantes responderam um questionário de múltipla escolha sobre o assunto abordado durante a aula teórica. Na sequencia foi realizada a aula prática correspondente à aula teórica ministrada. Após a aula prática, o mesmo questionário foi aplicado novamente. Desta maneira, foi possível analisar o rendimento e a eficiência das aulas práticas no aprendizado dos discentes. Os questionários foram aplicados aos alunos de forma virtual, por meio do ProProfs Online Quiz Maker Software (https://www.proprofs.com/quiz-school/).

\subsection{Tratamento dos Dados}

Os resultados obtidos através dos questionários aplicados como pré-testes e pós-testes foram tabulados na planilha do Excel® e apresentados em gráficos com percentual de acertos para cada questão. Análises com o uso de teste t-pareado e médias gerais de acerto foram realizadas para avaliar a eficácia da aula prática no processo de ensino-aprendizagem, através do software GraphPad Prism 6. Valores de $\mathrm{p}<0,05$ foram considerados estatisticamente significativos.

\subsection{Aspectos Éticos}

O desenvolvimento deste estudo foi devidamente aprovado e autorizado pelo Comitê de Ética e Pesquisa da UFMT (CAAE 16486719.7.0000.8088). Todos os participante desta pesquisa assinaram o Termo de Consentimento Livre e Esclarecido (TCLE) e o Termo de 
Assentimento Livre e Esclarecido (TALE).

\section{RESULTADOS}

Abaixo apresentamos os resultados da utilização das aulas práticas na eficiência do aprendizado dos discentes, a análise foi feita separadamente para cada prática incluída no presente estudo.

\subsection{Prática "extração do DNA da banana"}

Para análise da aula prática de extração do DNA da banana, foram consideradas as respostas de 26 alunos, que participaram do pré-teste e do pós-teste. As respostas de dois alunos que participaram apenas do pré-teste foram excluídas. A Figura 1 mostra a quantidade de acertos e erros (n) para cada questão antes da aplicação da aula prática (pré-teste). Com exceção das questões sete e 10, o número de erros foi bem maior do que o número de acertos antes da aplicação da aula prática.

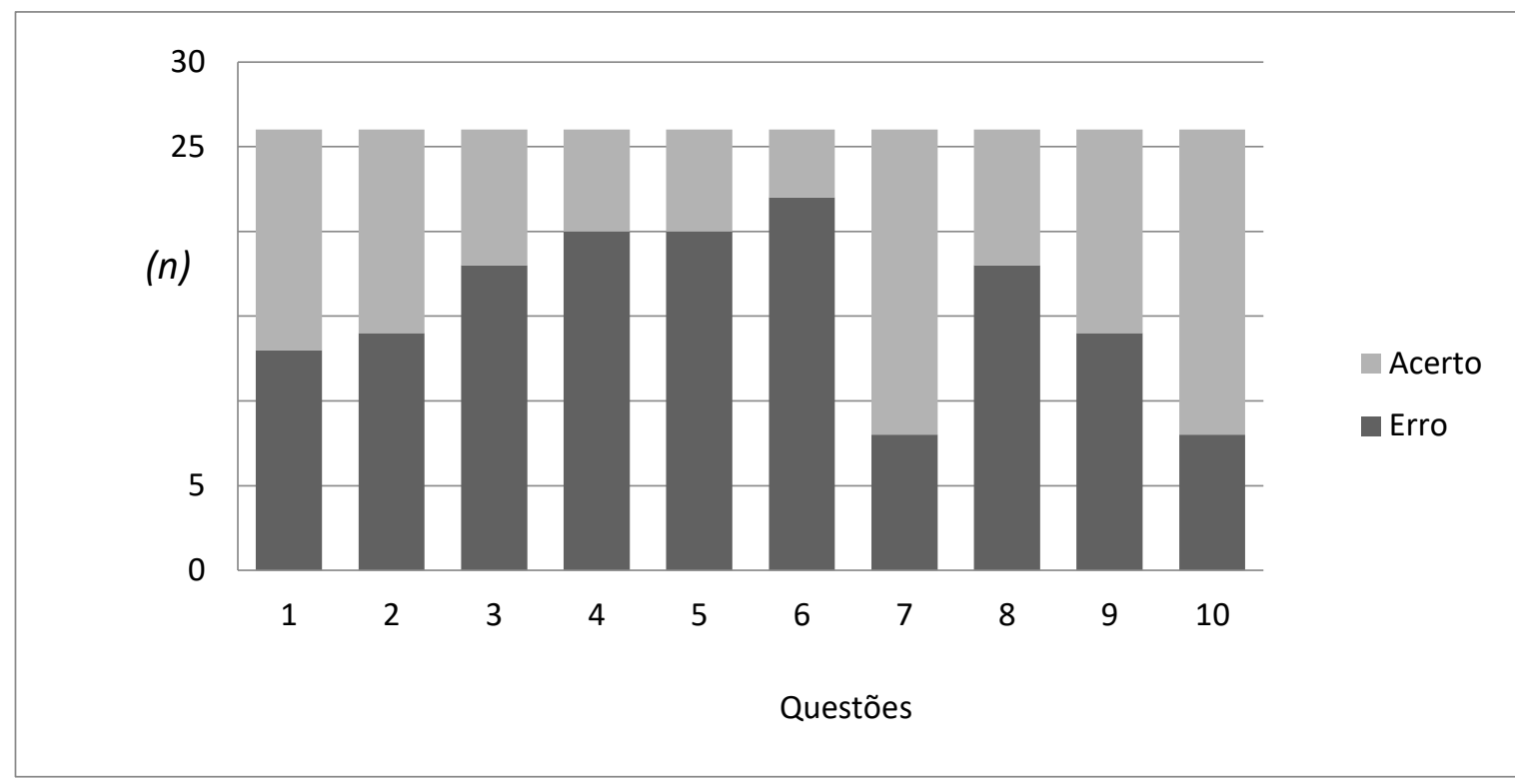

Figura 1- Rendimento dos discentes no pré-teste para aula "extração do DNA da banana". Os resultados são apresentados como números reais de acertos e erros (n).

A Figura 2 mostra a quantidade de acertos e erros para cada questão após a aplicação da aula prática (pós-teste). Em todas as questões houve aumento no número de acertos, porém, apenas para as questões três e quatro, o numero de acertos não superou o número de erros. 


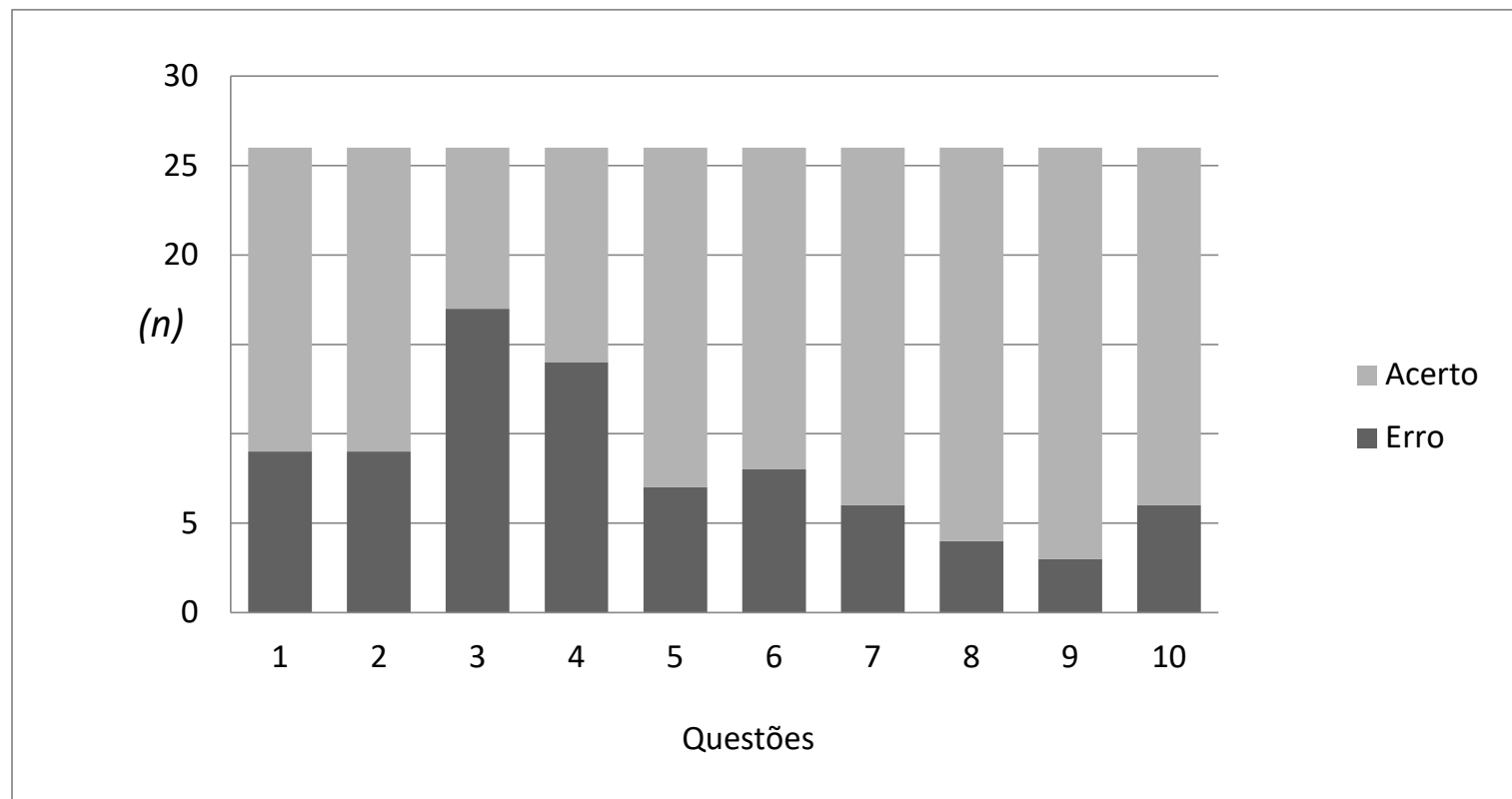

Figura 2 - Rendimento dos discentes nas questões aplicadas após a aula prática (pós-teste) “extração do DNA da banana". Os resultados são apresentados como números reais de acertos e erros (n).

A média geral de acertos e teste t-pareado foi calculado para avaliação da significância da aula prática. Na Figura 3 são apresentadas as médias de acertos das 10 questões aplicadas antes (pré-teste) e após (pós-teste) a execução da aula prática. Foi observado que no pré-teste, a média de acertos foi de $10,5 \pm 1,38$, enquanto no pós-teste foi de $17,7 \pm 2,02$, com valor de p em 0,0019 , mostrando que a aplicação da aula prática foi significativa para o processo de ensino-aprendizagem.

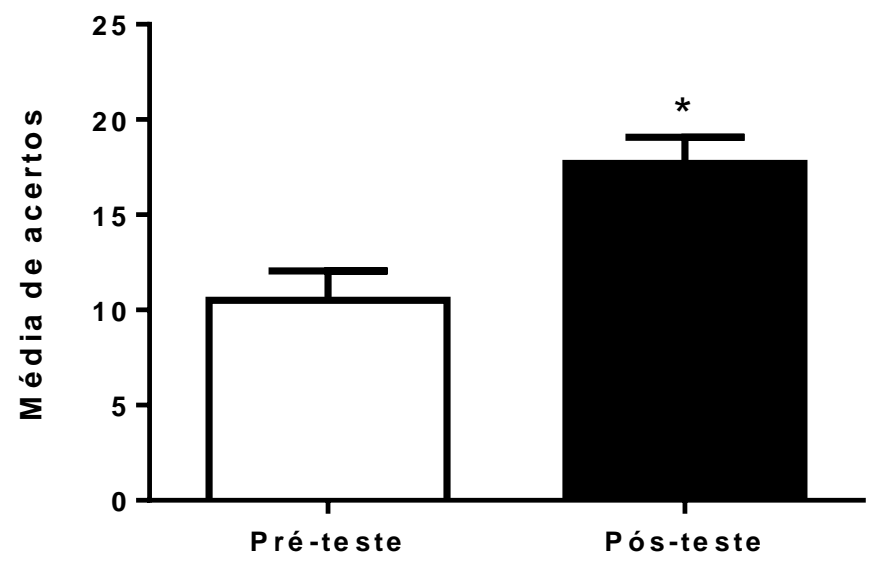

Figura 3 - Análise da média geral dos acertos das questões aplicadas antes e após a aplicação da aula prática "extração do DNA da banana". Os resultados são apresentados como média \pm erro padrão de cada grupo experimental. A Comparação estatística foi feita por One Sample t-test, sendo *p < 0,05 vs. Pré-teste. 


\subsection{Prática "Fermentação por microrganismos"}

Para análise da aula prática Fermentação por microrganismos, foram consideradas as respostas de 21 alunos, que participaram do pré-teste e do pós-teste. Dois participantes foram excluídos por terem participado apenas do pré-teste. A Figura 4 mostra a quantidade de acertos e erros (n) para cada questão antes da aplicação da aula prática (pré-teste). Com exceção das questões dois, três, seis e 10, o número de erros foi maior do que o número de acertos.

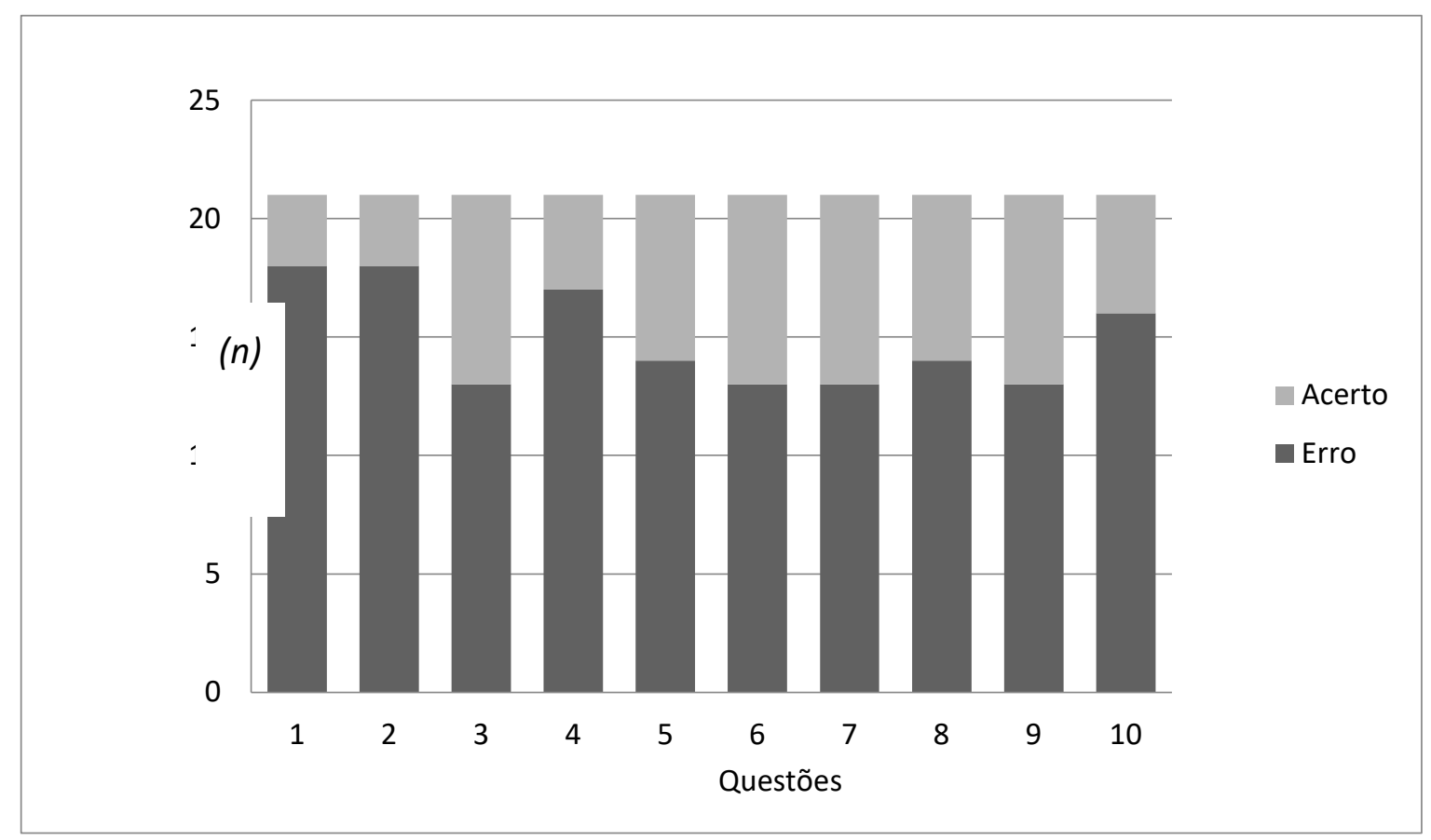

Figura 4 - Rendimento dos discentes nas questões aplicadas antes da aula prática (pré-teste) para aula "Fermentação por microrganismos". Os resultados são apresentados como números reais de acertos e erros (n).

A Figura 5 mostra a quantidade de acertos e erros para cada questão após a aplicação da aula prática (pós-teste). Em todas as questões houve aumento no número de acertos. 


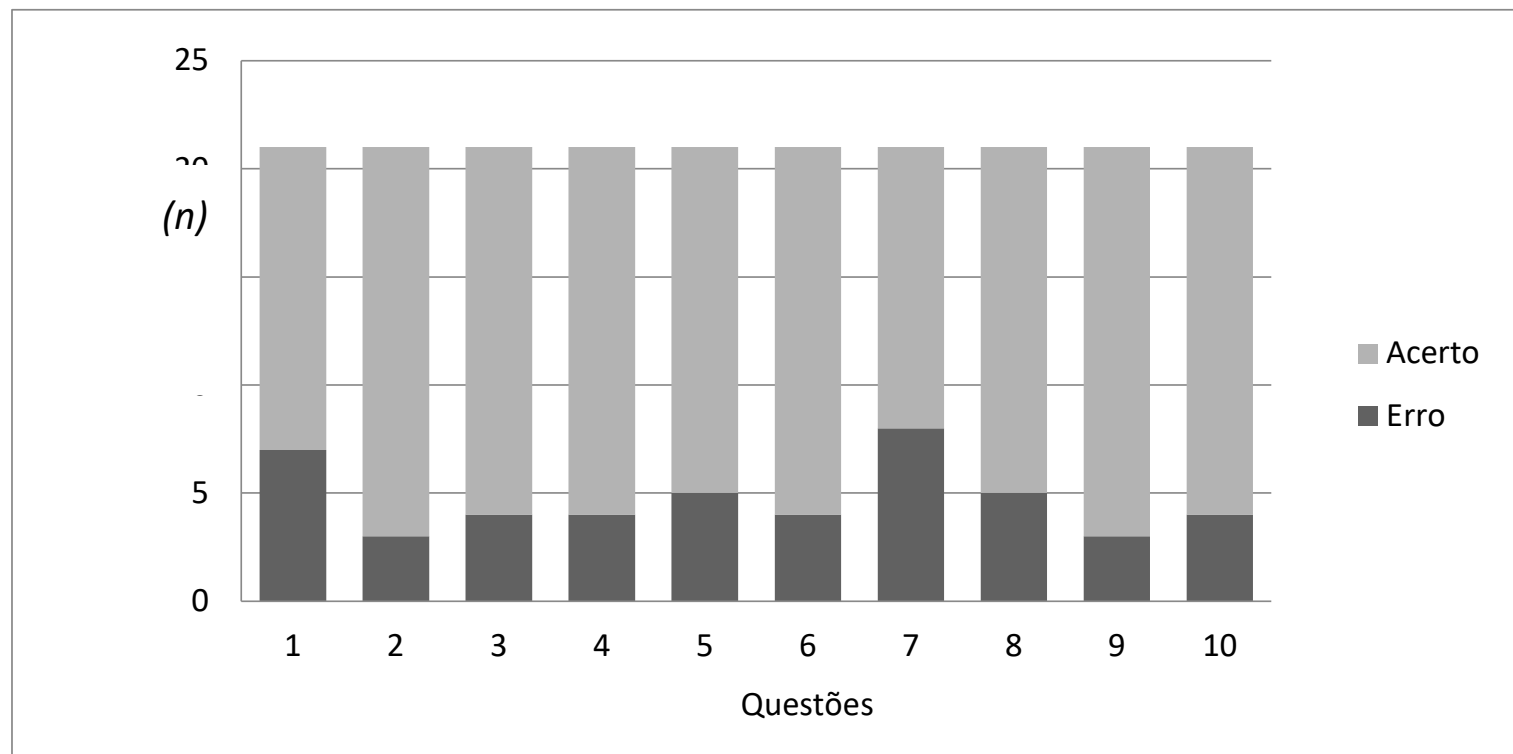

Figura 5 -Rendimento dos discentes nas questões aplicadas após a aula prática (pós-teste) "Fermentação por microrganismos". Os resultados são apresentados como números reais de acertos e erros (n).

A média geral de acertos e teste t-pareado foi calculado para avaliação da significância da aula prática. Na Figura 6 são apresentadas as médias de acertos das 10 questões aplicadas antes (pré-teste) e após (pós-teste) a execução da aula prática. Foi observado que no pré-teste, a média de acertos foi de $6,1 \pm 0,47$, enquanto no pós-teste foi de $16,3 \pm 1,77$, com valor de $p$ em 0,0001 , mostrando que a aplicação da aula prática foi significativa para o processo de ensino-aprendizagem.

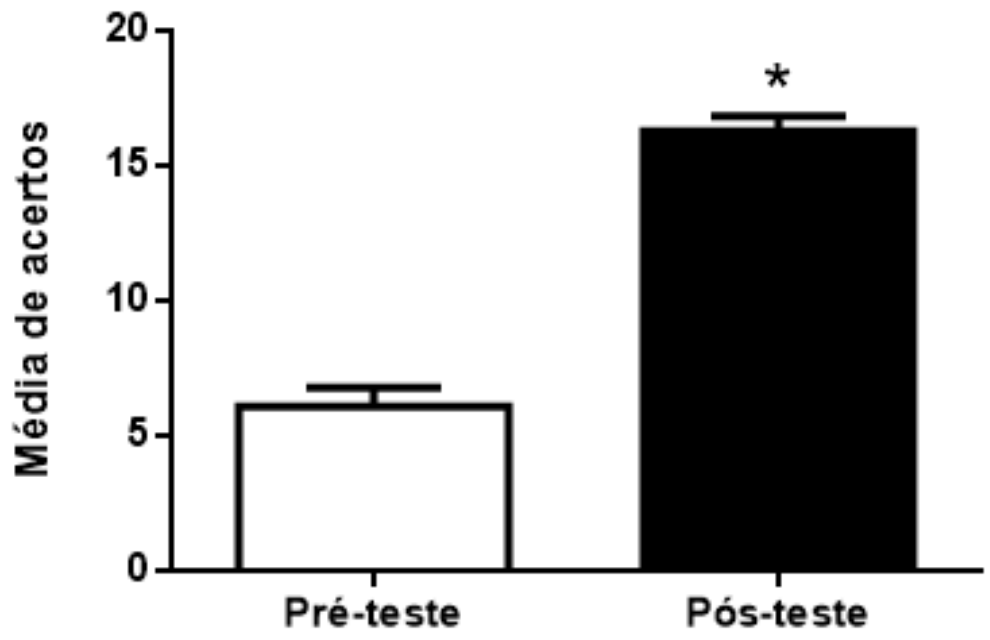

Figura 6 - Análise da média geral dos acertos das questões aplicadas antes e após a aplicação da aula prática "Fermentação por microrganismos". Os resultados são apresentados como média \pm erro padrão de cada grupo experimental. A Comparação estatística foi feita por One Sample t-test, sendo *p < 0,05 vs. Pré-teste. 


\subsection{Prática "Modelos Anatômicos com Materiais Reaproveitados"}

Para análise da aula prática de Modelos Anatômicos com Materiais Reaproveitados foram consideradas as respostas de 25 alunos, que participaram do pré-teste e do pós-teste. Nenhum participante foi excluído. A Figura 7 mostra a quantidade de acertos e erros (n) para cada questão antes da aplicação da aula prática (pré-teste). Com exceção da questão 10, em todas as questões, o número de erros foi bem maior do que o número de acertos.

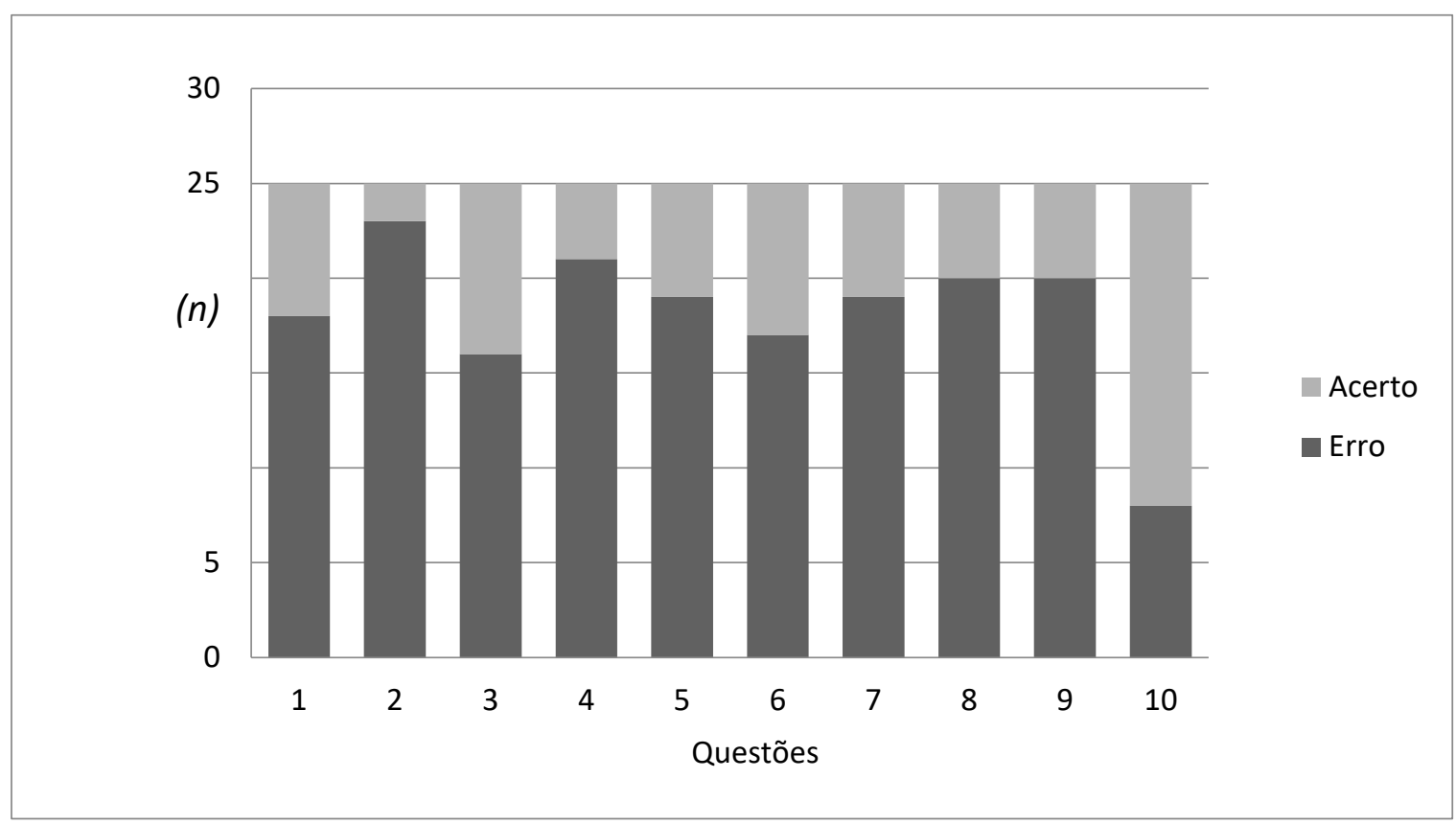

Figura 7 - Rendimento dos discentes nas questões aplicadas antes da aula prática (pré-teste) para aula "Modelos Anatômicos com Materiais Reaproveitados". Os resultados são apresentados como números reais de acertos e erros (n)

A Figura 8 mostra a quantidade de acertos e erros para cada questão após a aplicação da aula prática (pós-teste). Em todas as questões houve aumento no número de acertos, superando o número de erros. Para as questões três e 10, o numero de acertos foi de $100 \%$. 


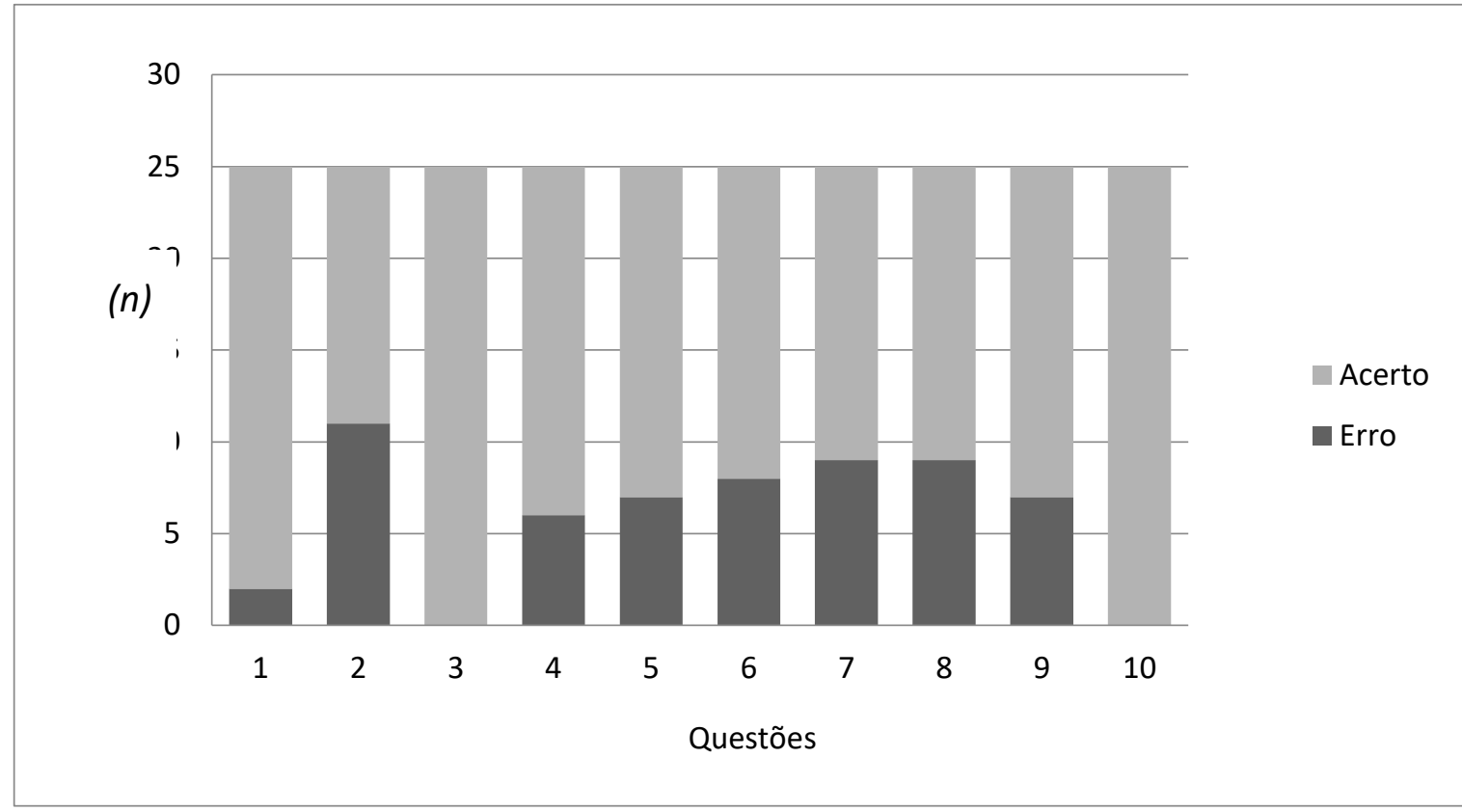

Figura 8. Rendimento dos discentes nas questões aplicadas após a aula prática (pós-teste) "Modelos Anatômicos com Materiais Reaproveitados". Os resultados são apresentados como números reais de acertos e erros (n).

A média geral de acertos e teste t-pareado foi calculado para avaliação da significância da aula prática. Na Figura 9 são apresentadas as médias de acertos das 10 questões aplicadas antes (pré-teste) e após (pós-teste) a execução da aula prática. Foi observado que no pré-teste, a média de acertos foi de $6,9 \pm 0,74$, enquanto no pós-teste foi de $19,1 \pm 2,28$, com valor de $p$ em 0,0001 , mostrando que a aplicação da aula prática foi significativa para o processo de ensino-aprendizagem.

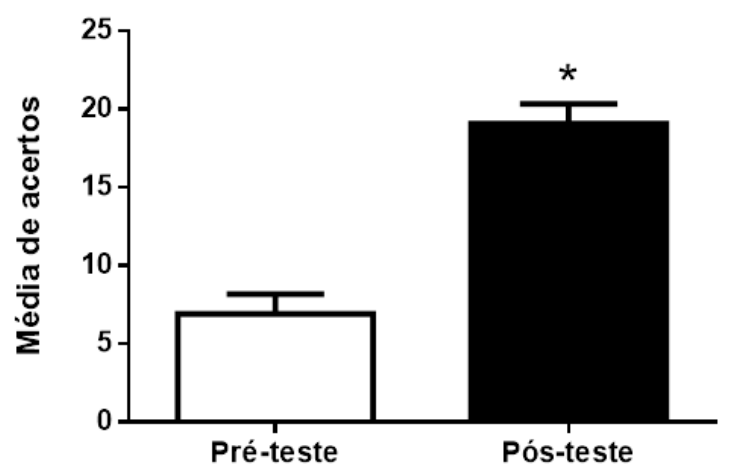

Figura 9 - Análise da média geral dos acertos das questões aplicadas antes e após a aplicação da aula prática "Modelos Anatômicos com Materiais Reaproveitados". Os resultados são apresentados como média \pm erro padrão de cada grupo experimental. A Comparação estatística foi feita por One Sample t-test, sendo *p < 0,05 vs. Pré-teste. 


\subsection{Prática "Sistema ABO e fator Rh"}

Para análise da aula prática Sistema $\mathrm{ABO}$ e fator $\mathrm{Rh}$, foram consideradas as respostas de 19 alunos, que participaram do pré-teste e do pós-teste. Quatro participantes foram excluídos, três por terem participado apenas do pré-teste e um por ter participado apenas do pós-teste. A Figura 10 mostra a quantidade de acertos e erros (n) para cada questão antes da aplicação da aula prática (pré-teste). Com exceção das questões dois, três, seis e 10, o número de erros foi maior do que o número de acertos.

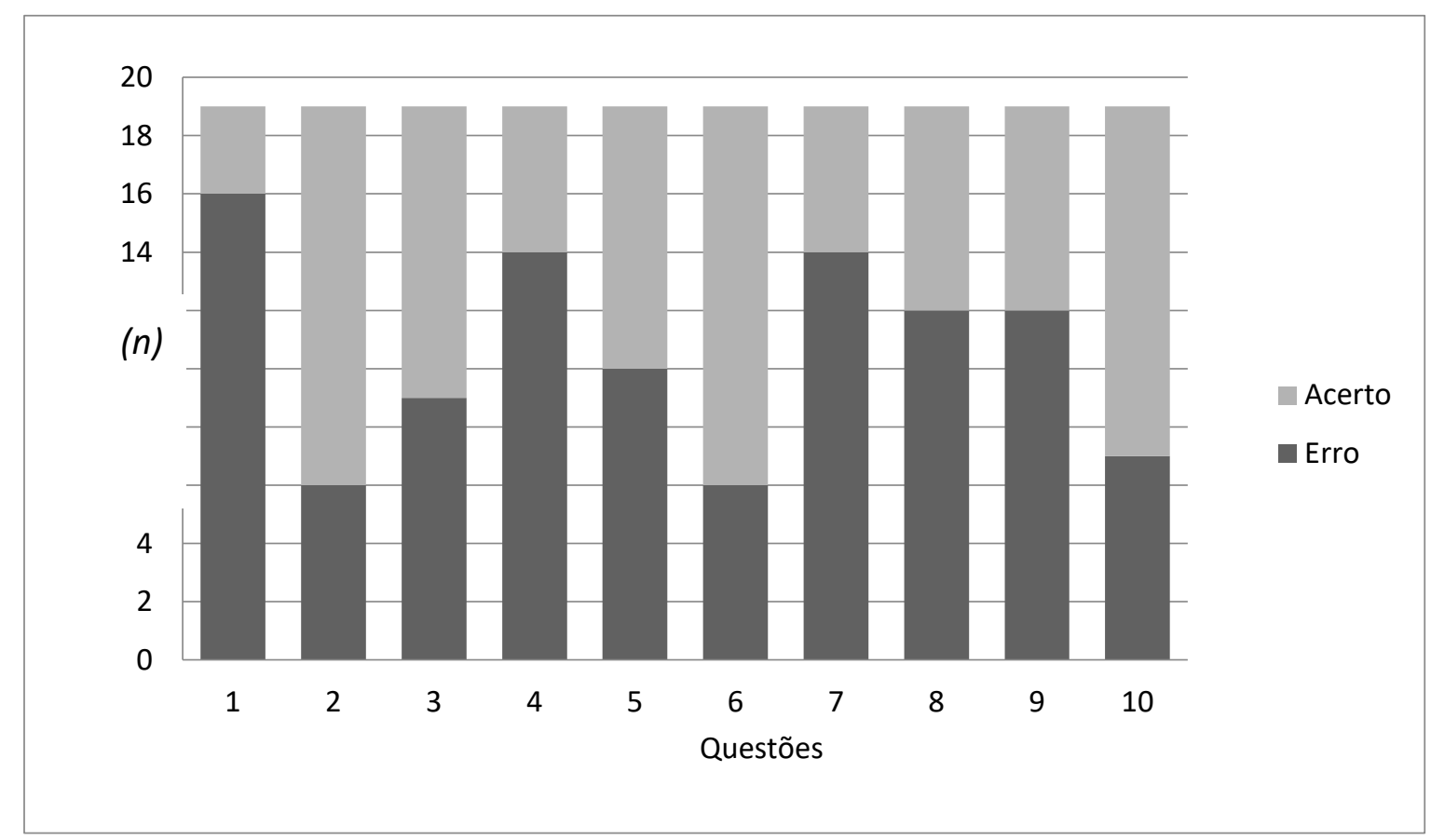

Figura 10 - Rendimento dos discentes nas questões aplicadas antes da aula prática (pré-teste) para aula “Sistema ABO e fator Rh". Os resultados são apresentados como números reais de acertos e erros (n).

A Figura 11 mostra a quantidade de acertos e erros para cada questão após a aplicação da aula prática (pós-teste). Em todas as questões houve aumento no número de acertos. Apenas na questão nove o número de acertos não superou o número de erros. 


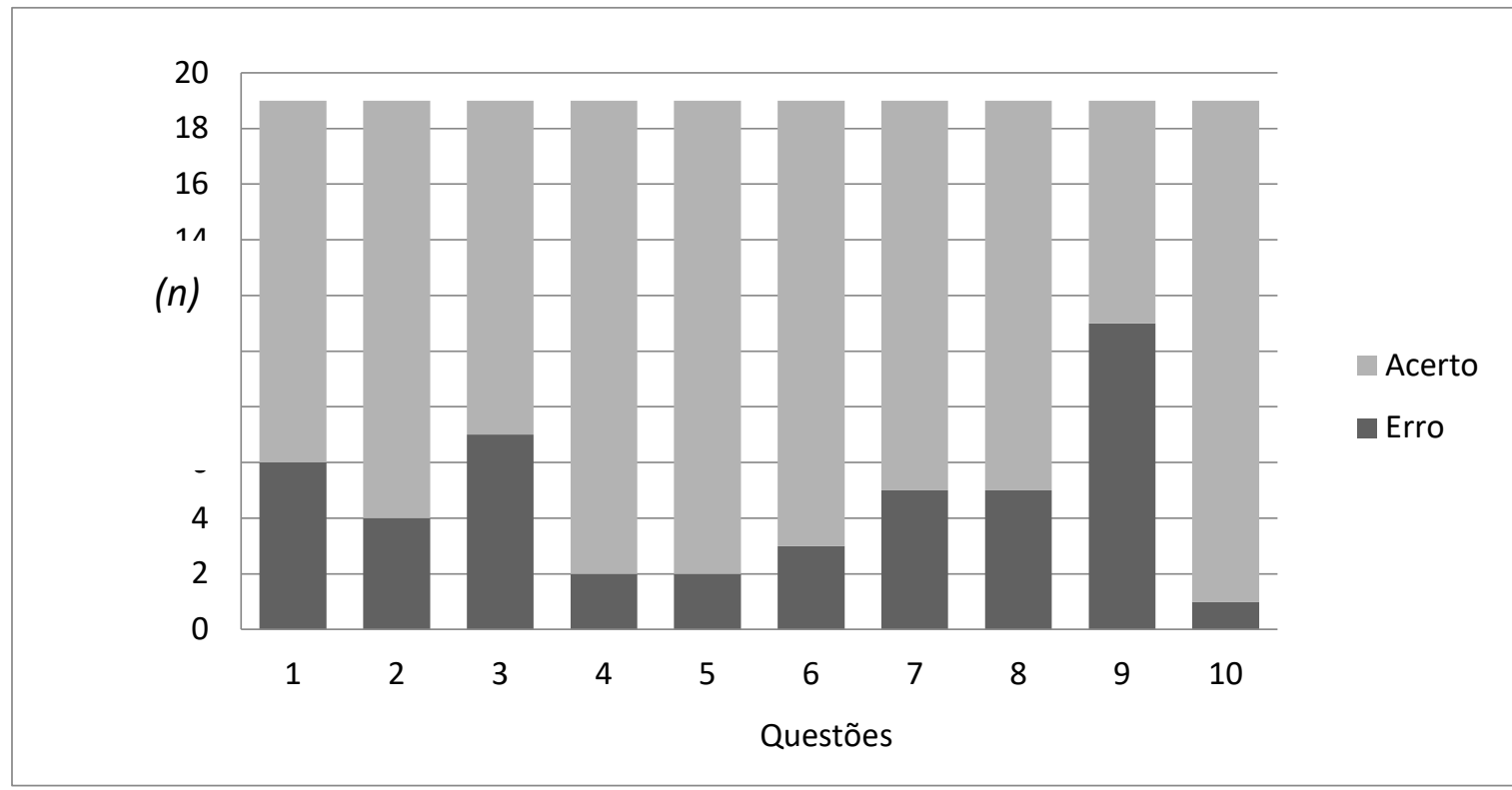

Figura 11 - Rendimento dos discentes nas questões aplicadas após a aula prática (pós-teste) "Sistema $\mathrm{ABO}$ e fator Rh”. Os resultados são apresentados como números reais de acertos e erros (n).

A média geral de acertos e teste t-pareado foi calculado para avaliação da significância da aula prática. Na Figura 12 são apresentadas as médias de acertos das 10 questões aplicadas antes (pré-teste) e após (pós-teste) a execução da aula prática. Foi observado que no pré-teste, a média de acertos foi de $8,4 \pm 0,92$, enquanto no pós-teste foi de $14,4 \pm 1,68$, com valor de $\mathrm{p}$ em 0,0008 , mostrando que a aplicação da aula prática foi significativa para o processo de ensino-aprendizagem.

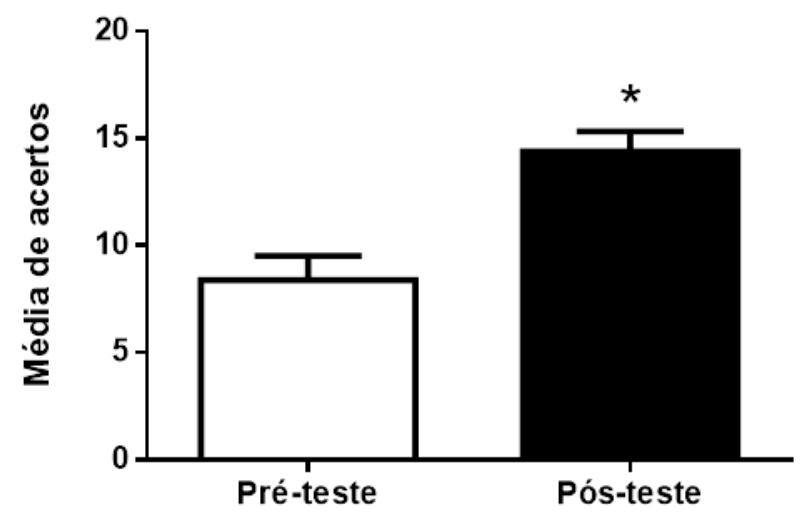

Figura 12 - Análise da média geral dos acertos das questões aplicadas antes e após a aplicação da aula prática "Sistema $\mathrm{ABO}$ e fator Rh". Os resultados são apresentados como média \pm erro padrão de cada grupo experimental. A Comparação estatística foi feita por One Sample t-test, sendo *p $<0,05$ vs. Pré-teste.

\subsection{Prática "Evolução - Seleção Natural em Tentilhões"}

Para análise da aula prática da Evolução - Seleção Natural em Tentilhões foram 
consideradas as respostas de 25 alunos, que participaram do pré-teste e do pós-teste. As respostas de três alunos que participaram apenas do pré-teste foram excluídas. A Figura 13 mostra a quantidade de acertos e erros (n) para cada questão antes da aplicação da aula prática (pré-teste). Em todas as questões, o número de erros foi bem maior do que o número de acertos antes da aplicação da aula prática.

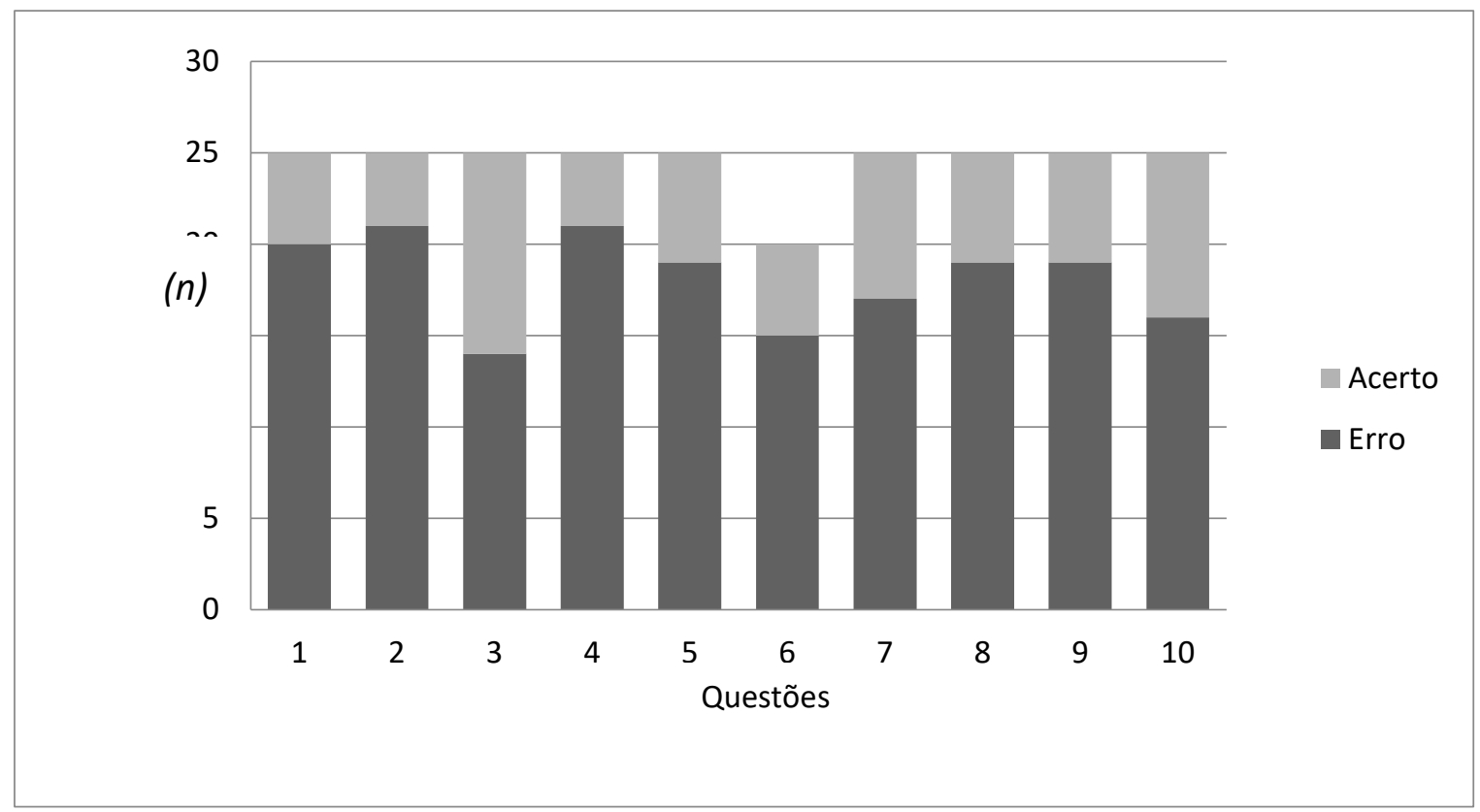

Figura 13 - Rendimento dos discentes nas questões aplicadas antes da aula prática (pré-teste) para aula "Evolução - Seleção Natural em Tentilhões". Os resultados são apresentados como números reais de acertos e erros (n).

A Figura 14 mostra a quantidade de acertos e erros para cada questão após a aplicação da aula prática (pós-teste). Em todas as questões houve aumento no número de acertos, superando o número de erros. 


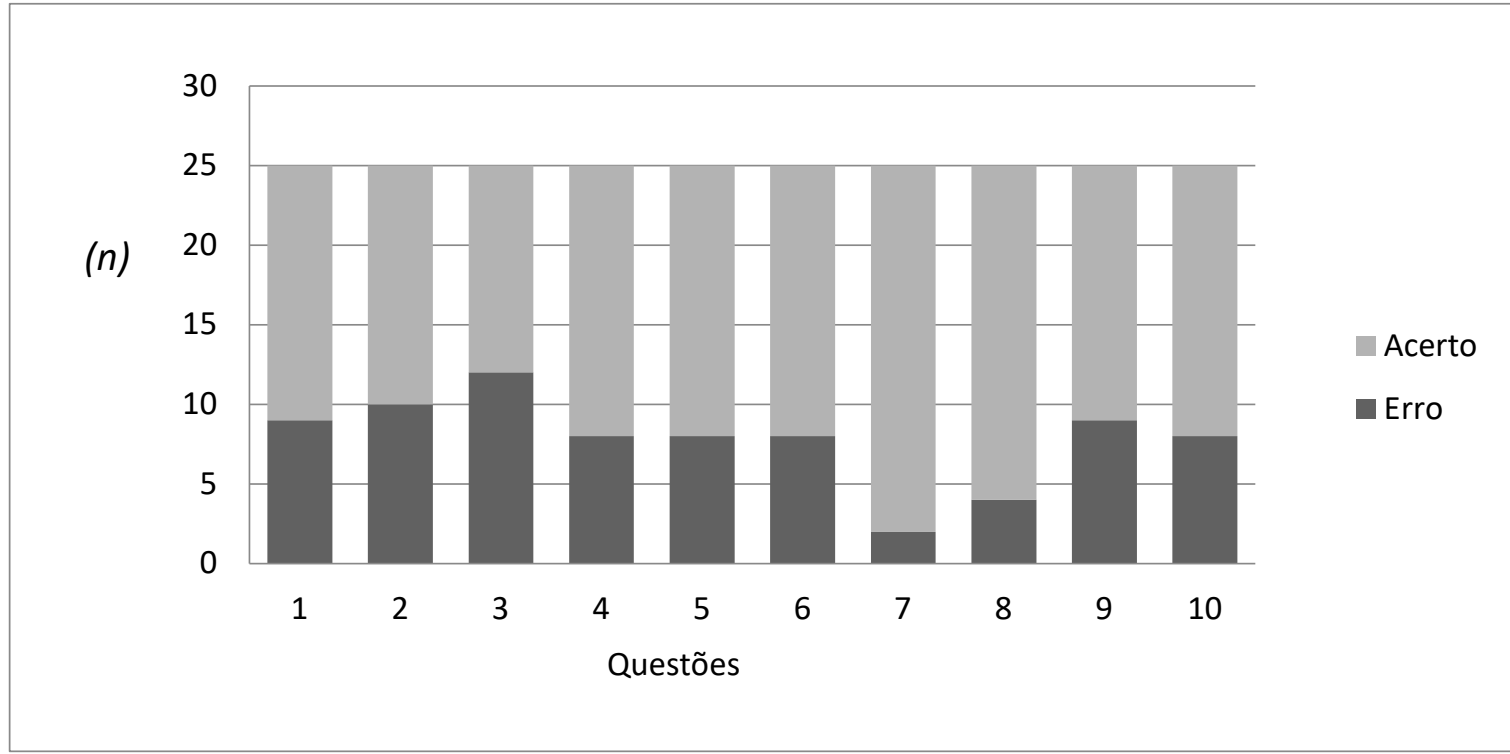

Figura 14 - Rendimento dos discentes nas questões aplicadas após a aula prática (pós-teste) "Evolução - Seleção Natural em Tentilhões”. Os resultados são apresentados como números reais de acertos e erros (n).

A média geral de acertos e teste t-pareado foi calculado para avaliação da significância da aula prática. Na Figura 15 são apresentadas as médias de acertos das 10 questões aplicadas antes (pré-teste) e após (pós-teste) a execução da aula prática. Foi observado que no pré-teste, a média de acertos foi de $6,4 \pm 0,79$, enquanto no pós-teste foi de $17,2 \pm 1,98$, com valor de $\mathrm{p}$ em 0,0001 , mostrando que a aplicação da aula prática foi significativa para o processo de ensino-aprendizagem.

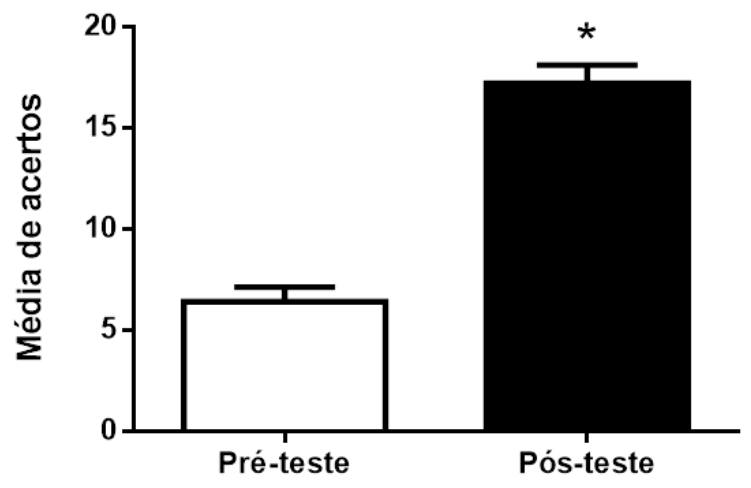

Figura 15 - Análise da média geral dos acertos das questões aplicadas antes e após a aplicação da aula prática "Evolução - Seleção Natural em Tentilhões". Os resultados são apresentados como média \pm erro padrão de cada grupo experimental. A Comparação estatística foi feita por One Sample t-test, sendo *p < 0,05 vs. Préteste. 


\section{DISCUSSÃO}

Como mencionado anteriormente, nossos resultados mostraram diferenças significativas entre as respostas dos alunos, quando comparados os questionários aplicados antes e após a realização de todas as aulas práticas. Durante todas as aulas práticas foi constatada maior participação e interesse pelo assunto, por parte dos alunos, corroborando outros estudos que apontam que aulas práticas aumentam o interesse dos discentes, além de enfatizar a importância da aplicação de aulas práticas para o processo de ensino-aprendizagem (LEITE et al., 2005; SOARES \& BAIOTTO, 2015).

Não é de hoje que a experimentação científica é exaltada e tida por professores e alunos como parte essencial na complementação da formação básica. Mas sua execução ainda está distante do ideal na maior parte das escolas brasileiras, pois a falta de estrutura adequada, falha na formação dos professores e ambiente inadequado nas salas de aulas são algumas das razões que impossibilitam a sua realização. Dentro desta perspectiva, é extremamente importante demonstrar como a realização de aulas práticas pode contribuir positivamente no processo de ensino-aprendizagem em biologia (SOUZA \& SANTOS, 2019).

As práticas abordadas no presente estudo corroboram com parte dos objetivos das metodologias ativas, por tratarem os alunos como protagonistas, estimulando a criatividade e deixando-os com autonomia para desenvolver as atividades necessárias (MORZELE et al., 2019). De acordo com Torres et al., (2019), é na clareza do cenário educacional do momento, em que se aflora a aprendizagem onipresente, de modo que seja necessário rever o processo de ensino- aprendizagem, tendo em mente o papel do aluno-protagonista, autônomo em seu aprendizado. Deste modo é que as metodologias ativas surgem como alternativa para uma educação moderna e alinhada com as novas exigências de construção do conhecimento (HENZ et al., 2019).

Durante a aplicação de todas as aulas práticas, surgiram dúvidas e arguições de diversas naturezas, por parte dos alunos, que foram tratadas como problematizações. Assim, eles foram encorajados a buscarem pelas respostas, para que elas fossem discutidas posteriormente em outros momentos. Freire (2003) defende a educação problematizadora, outro aspecto relevante das aulas práticas apresentadas no guia desenvolvido neste estudo, que corrobora com o cumprimento das metodologias ativas. Para Freire (2003), problematizar é estreitar as relações entre homem e mundo através de uma análise crítica e reflexiva. A problematização torna o aluno protagonista, pois diferentemente dos métodos tradicionais de 
ensino, ela instiga o aluno a buscar livremente pela solução de um determinado problema (ARAGÃO et al., 2019).

Esse encorajamento aos alunos para que buscassem sozinhos os assuntos que respondessem as indagações que surgiram durante as aulas práticas, para que fossem discutidas em uma aula posterior, também pode ser caracterizada como sala de aula invertida (PAIVA et al., 2016; BOLLELA, 2017; LIMA-JUNIO et al., 2017; DIESEL et al., 2017). A sala de aula invertida, também denominada Flipped classroom, forma um modelo de ensino, onde os alunos estudam os conteúdos em casa, antes das aulas mediadas por professores, de modo que, posteriormente, em sala de aula, realizem as atividades propostas relacionadas aos assuntos abordados (SANCHES et al., 2019). Assim, todo o processo de ensino se torna mais ativo, onde os alunos se tornam os centros das atenções, como protagonistas, ao passo que o professor atua na mediação, organização e condução das atividades de ensino, tirando dúvidas, guiando o aluno, enfatizando as partes mais importantes dos temas abordados e instigando discussões (DE CASTRO \& GOLDSCHMIDT, 2016; GOMES; SOUZA, 2017; MERIGUETE et al., 2019). Podemos observar que as aulas práticas abordadas no presente estudo, encorajaram os alunos a também buscarem na literatura por assuntos não abordados, mas relacionados às aulas, reforçando a importância da autonomia do discente no processo de ensino e aprendizagem.

Nos últimos anos, vários estudos demonstraram a importância da aplicação das aulas práticas para melhor assimilação dos conteúdos presentes nos componentes curriculares. O estudo realizado por Leite et al., (2005), objetivou analisar a importância das aulas práticas no ensino de Ciências Naturais para os alunos de duas turmas, com perfis diferentes, do Segundo Segmento do Projeto de Ensino Fundamental de Jovens e Adultos da Universidade Federal de Minas Gerais (PROEF II), os autores concluíram que as aulas práticas foram extremamente importantes para o aprendizado dos alunos, os autores observaram que as aulas práticas serviram tanto como ferramentas para complementar os ensinos teóricos, quanto para motivar os alunos.

Outro estudo em que os resultados se assemelharam com os encontrados no presente estudo, foi realizado por Bartzik \& Zander (2016), objetivando discutir a importância das aulas práticas de Ciências desenvolvidas no ensino fundamental de uma determinada escola particular do município de Cascavel-PR. Através da aplicação de questionários, os autores supra citados observaram que a maior parte dos alunos entrevistados julgaram as atividades práticas como altamente relevantes para o processo de ensino-aprendizagem. $\mathrm{O}$ 
desenvolvimento e avaliação das aulas experimentais apresentadas por eles, mostraram também a importância das aulas práticas para o processo de ensino-aprendizagem, tendo em vista que houve um aumento significativo no desempenho dos alunos após a aplicação das aulas práticas (BARTZIK \& ZANDER, 2016).

\section{CONSIDERAÇÕES}

O estudo mostrou que a aplicação de aulas práticas foi significativa no aprendizado do discente, não só por proporcionar uma melhor visualização, mas também por motivar e instigar os alunos a buscarem por assuntos não apresentados, mas relacionados, às aulas práticas. Com base no presente estudo, pode-se afirmar que as cinco aulas práticas apresentadas aqui foram eficazes para o processo de ensino-aprendizagem, além de não exigirem materiais de difícil acesso e nem ambientes especializados, podendo ser aplicadas em salas ou espaços de recreação escolar.

\section{REFERÊNCIAS}

ARAGÃO, A. A. S.; SILVA, J. J. J.; MENDES, M. S. Ensino de ciências por investigação: o aluno como protagonista do conhecimento. Revista Vivências em Ensino de Ciências, p. 75, 2019. https://periodicos.ufpe.br/revistas/vivencias/article/view/243819/34097

BARBOSA, Altemir José Gonçalves; CAMPOS, Renata Araújo; VALENTIM, Tássia Azevedo. A diversidade em sala de aula e a relação professor-aluno. Estudos de Psicologia (Campinas), v. 28, p. 453-461, 2011. https://doi.org/10.1590/S0103-166X2011000400006

BARBOSA, E. F.; MOURA, D. G. Metodologias ativas na aprendizagem de educação profissional e tenológica. Boletim Técnico do SENAC, v. 39, n. 2, p. 48-67, 2013.

BARTZIK, Franciele; ZANDER, Leiza Daniele. A importância das aulas práticas de ciências no ensino fundamental. Revista@ rquivo Brasileiro de Educação, Belo Horizonte, v. 4, n. 8, p. 31-38, 2016. https://doi.org/10.5752/P.2318-7344.2016v4n8p31

BOLLELA, V. R.. Sala de aula invertida na educação para as profissões de saúde: conceitos essenciais para a prática. Revista Eletrônica de Farmácia, v. 14, n. 1, 2017. https://doi.org/10.5216/ref.v14i1.42807.

CASTRO, T. F.; GOLDSCHMIDT, A. I. Aulas práticas em ciências: concepções de estagiários em licenciatura em biologia e a realidade durante os estágios. Amazônia: Revista de Educação em Ciências e Matemáticas, v. 13, n. 25, p. 116-134, 2016. https://periodicos.ufpa.br/index.php/revistaamazonia/article/view/3800/4047 
DIESEL, A.; BALDEZ, A. L. S.; MARTINS, S. N. Os princípios das metodologias ativas de ensino: uma abordagem teórica. Revista Thema, v. 14, n. 1, p. 268-288, 2017.https://doi.org/10.15536/thema.14.2017.268-288.404

FILHOAIS, C.; TRINDADE, J. Física no Computador: O Computador como uma Ferramenta no Ensino e na Aprendizagem das Ciências Físicas. Revista Brasileira de Ensino de Física, v. 25, n. 3, 2003. https://doi.org/10.1590/S1806-11172003000300002

FREIRE, Paulo. Pedagogia da autonomia: saberes necessários à prática educativa. São Paulo: Paz e Terra, 2003.

GOMES, P. W. P.; SOUZA, R. F. O uso de um laboratório portátil com materiais reciclados nas aulas práticas de ciências naturais/The use of a portable laboratory built with recycled materials for practical classes in natural sciences. Revista Areté| Revista Amazônica de Ensino de Ciências, v. 10, n. 22, p. 74-83, 2017.

http://periodicos.uea.edu.br/index.php/arete/article/view/632/601

HENZ, F.; MARTINS, S. N.; SINDELAR, F. C. W. metodologias ativas de ensino na universidade: uma experiência na disciplina de economia brasileira. Imagens da Educação, v. 9, n. 3, p. 12-25, 2019. https://doi.org/10.4025/imagenseduc.v9i3.33949

LEITE, A. C. S.; SILVA, P. A. B.; VAZ, A. C. R. A importância das aulas práticas para alunos jovens e adultos: uma abordagem investigativa sobre a percepção dos alunos do PROEF II. Ensaio pesquisa em educação em ciências (belo horizonte), v. 7, n. 3, p. 166181, 2005. https://doi.org/10.1590/1983-21172005070302

LIMA, D. B.; GARCIA, R. N. Uma investigação sobre a importância das aulas práticas de Biologia no Ensino Médio. Cadernos de Aplicação, v. 24, n. 1, 2011. https://doi.org/10.22456/2595-4377.22262

LIMA, R. M. de. Utilização de modelos didáticos de artrópodes como ferramenta de aprendizagem no ensino de ciências e biologia. $2017.51 \mathrm{f}$. TCC - Universidade Federal da Paraíba, Areia, 2017. Disponível em:

https://repositorio.ufpb.br/jspui/bitstream/123456789/2307/1/RML09082017.pdf. Acesso em: 15 jan. 2019.

LIMA-JUNIOR, C. G., ARAÚJO CAVALCANTE, A. M., LIMA OLIVEIRA, N., SANTOS, G. F., \& MONTEIRO-JÚNIOR, J. M. A. Sala de aula invertida no ensino de química: planejamento, aplicação e avaliação no ensino médio. Revista Debates em Ensino de Química, v. 3, n. 2, p. 119-145, 2017. http://www.journals.ufrpe.br/index.php/REDEQUIM/article/view/1787/1589

LUZ, Priscyla Santiago; LIMA, Josiane Ferreira; AMORIM, Thamiris Vasconcelos. Aulas práticas para o ensino de Biologia: contribuições e limitações no Ensino Médio. Revista de Ensino de Biologia da SBEnBio, p. 36-54, 2018. https://doi.org/10.46667/renbio.v11i1.107

MERIGUETE, M. S. P., SANTOS, A. P., SILVA, M. R., ROMANHA, W. R., PASSOS, M. L. S., \& CARVALHO, D. V.. Sala de Aula Invertida e Rotação por Estações: aplicação no projeto social Grupo Bizu de Prova. Em Rede-Revista de Educação a Distância, v. 6, n. 2, 
p. 288-307, 2019. file:///C:/Users/katia/Downloads/465-Texto\%20do\%20artigo-2575-1-1020190916.pdf

MITRE, S. M.; SIQUEIRA-BATISTA, R.; GIRARDI-DE-MENDONÇA, J. M.; MORAISPINTO, N. M. D.; MEIRELLES, C. D. A. B.; PINTO-PORTO, C.; HOFFMANN, L. M. A.. Metodologias ativas de ensino-aprendizagem na formação profissional em saúde: debates atuais. Ciência \& saúde coletiva, v. 13, p. 2133-2144, 2008. https://doi.org/10.1590/S1413$\underline{81232008000900018}$

MORZELE, A.; SANTOS, M. L.; STIES, S. W. Inovando em sala de aula na atenção à saúde da mulher e do homem utilizando como recurso as metodologias ativas. Cadernos de educação, saúde e fisioterapia, v. 6, n. 12, 2019.

PAIVA, M. R. F.; PARENTE, J. R. F.; BRANDÃO, I. R.; QUEIROZ, A. H. B. Metodologias ativas de ensino-aprendizagem: revisão integrativa. SANARE-Revista de Políticas Públicas, v. 15, n. 2, 2016. file:///C:/Users/katia/Downloads/1049-2481-1-SM.pdf

POSSOBOM, C. C. F.; OKADA, F. K.; DINIZ, R. E. S. Atividades práticas de laboratório no ensino de biologia e de ciências: relato de uma experiência. Núcleos de ensino. São Paulo:

Unesp, Pró-reitora de Graduação, p. 113-123, 2003.

file:///C:/Users/katia/Downloads/atividadespraticas.pdf

ROCHA, J. B. T.; SOARES, F. A. O ensino de ciências para além do muro do construtivismo. Ciência e cultura, v. 57, n. 4, p. 26-27, 2005.

http://cienciaecultura.bvs.br/pdf/cic/v57n4/a16v57n4.pdf

SANCHES, R. M. L.; BATISTA, S. C. F.; SOUZA, V. M. Sala de Aula Invertida em aulas de Matemática Financeira Básica no Ensino Médio: reflexões sobre atividades e recursos didáticos digitais. RENOTE-Revista Novas Tecnologias na Educação, v. 17, n. 1, p. 476485, 2019. https://doi.org/10.22456/1679-1916.95858

SANTIAGO, S. A.; CARVALHO, H. F. Estratégia de ensino: Aprenda em sala de aula. Revista de Ensino de Bioquímica, v. 16, n. 1, p. 51-73, 2018.

http://dx.doi.org/10.16923/reb.v16i1.787

SCHNEIDER, E. I.; SUHR, I. R. F.; ROLON, V. E.; ALMEIDA, C. M.. Sala de Aula invertida em EAD: uma proposta de Blended Learning. Revista Intersaberes, v. 8, n. 16, p. 68-81, 2013. https://doi.org/10.22169/revint.v8i16.499

SILVA, R. F.; SILVA, B. B.; SILVA, N. P. O.; BEZERRA, M. L. D. M. B.; ARAÚJO, S. L. S. M. A concepção dos alunos do Ensino Médio sobre a importância das aulas práticas de Biologia. Diversitas Journal, v. 3, n. 3, p. 564-568, 2018. https://doi.org/10.17648/diversitas-journal-v3i3.509

SOARES, R. M.; BAIOTTO, C. R. Aulas práticas de biologia: suas aplicações e o contraponto desta prática. Di@ logus, v. 4, n. 2, p. 53-68, 2015.

SOUZA, C. M.; SANTOS, C. B. Aulas Práticas no ensino de Biologia: Desafios e Possibilidades/Practical Lessons in Biology Education: Challenges and Possibilities. ID on 
line REVISTA DE PSICOLOGIA, v. 13, n. 45, p. 426-433, 2019.

file:///C:/Users/katia/Downloads/1839-7111-1-PB.pdf

SUHR, I. R. F. Desafio do uso da sala de aula invertida no ensino superior. R. Transmutare, Curitiba, v. 1, n. 1, p. 4-21, jan./jun. 2016. file:///C:/Users/katia/Downloads/3872-15293-2PB.pdf

TORRES, Leonardo et al. Poetas de escola: espaço de empoderamentos, territórios e identidades. Revista TransVersos, n. 17, p. 178-202, 2019.

10.12957/transversos.2019.47297.

VALENTE, J. A. A sala de aula invertida e a possibilidade do ensino personalizado: uma experiência com a graduação em midialogia. Metodologias Ativas para uma Educação Inovadora: Uma Abordagem Teórico-Prática. Porto Alegre: Penso Editora, 2017. https://statics-submarino.b2w.io/sherlock/books/firstChapter/132759983.pdf

\section{APÊNDICE 1}

\section{AGRADECIMENTOS}

Ao programa de Pós-graduação Mestrado Profissional em Ensino de Biologia (PROFBio-UFMT), pela oportunidade. À Coordenação de Aperfeiçoamento de Pessoal de Nível Superior - Brasil (CAPES), pelo apoio financeiro. Ao Instituto de Biociências/UFMT, pela infraestrutura cedida. À Secretaria Estadual de Educação Seduc. Pela leitura crítica do manuscrito somos gratas ao Pablo Henrique Delmondes, à Daniela Silva Sartori Delmondes e a Carmen Eugenia Rodriguez Ortiz.

\section{FINANCIAMENTO}

Agradeço o apoio da Coordenação de Aperfeiçoamento de Pessoal de Nível Superior -Brasil (CAPES) -Código de Financiamento 001.

\section{CONTRIBUIÇÕES DE AUTORIA}

Resumo/Abstract/Resumen: Susane Silva Sartori/Katiane Mara Ferreira/Carmen Eugenia Rodriguez Ortiz Introdução: Susane Silva Sartori/Katiane Mara Ferreira

Análise de dados: Susane Silva Sartori/Katiane Mara Ferreira

Discussão dos resultados: Susane Silva Sartori/Katiane Mara Ferreira

Conclusão e considerações finais: Susane Silva Sartori/Katiane Mara Ferreira

Referências: Susane Silva Sartori/Katiane Mara Ferreira

Revisão do manuscrito: Susane Silva Sartori/Katiane Mara Ferreira

\section{CONFLITOS DE INTERESSE}

As autoras declararam não haver nenhum conflito de interesse de ordem pessoal, comercial, acadêmico, político e financeiro referente a este manuscrito.

\section{DISPONIBILIDADE DE DADOS DE PESQUISA}

O conjunto de dados que dá suporte aos resultados da pesquisa foi publicado no próprio artigo.

\section{CONSENTIMENTO DE USO DE IMAGEM}

Não se aplica.

\section{APROVAÇÃO DE COMITÊ DE ÉTICA EM PESQUISA}

Atendendo ao rigor ético e científico, a pesquisa foi encaminhada ao Comitê de Ética em Pesquisa (CEP) da Universidade Federal de Mato Grosso e aprovada sob o n 16486719.7 .0000 .8088$. 


\section{COMO CITAR - ABNT}

SARTORI, Susane Silva; FERREIRA, Katiane Mara. Testando a eficiência das aulas práticas no aprendizado de Biologia para o Ensino Médio, a partir de materiais de baixo custo. REAMEC - Rede Amazônica de Educação em Ciências e Matemática. Cuiabá, v. 9, n. 3, Cuiabá, e21097, set./dez., 2021. http://dx.doi.org/10.26571/reamec.v9i3.12866.

\section{COMO CITAR - APA}

Sartori, S.S.; Ferreira, K.M. (2021). Testando a eficiência das aulas práticas no aprendizado de Biologia para o Ensino Médio, a partir de materiais de baixo custo. REAMEC - Rede Amazônica de Educação em Ciências e Matemática. Cuiabá, 9(3), e21097. http://dx.doi.org/ 10.26571/reamec.v9i3.12866.

\section{LICENÇA DE USO}

Licenciado sob a Licença Creative Commons Attribution-NonCommercial 4.0 International (CC BY-NC 4.0). Esta licença permite compartilhar, copiar, redistribuir o manuscrito em qualquer meio ou formato. Além disso, permite adaptar, remixar, transformar e construir sobre o material, desde que seja atribuído o devido crédito de autoria e publicação inicial neste periódico.

\section{DIREITOS AUTORAIS}

Os direitos autorais são mantidos pelos autores, os quais concedem à Revista REAMEC - Rede Amazônica de Educação em Ciências e Matemática - os direitos exclusivos de primeira publicação. Os autores não serão remunerados pela publicação de trabalhos neste periódico. Os autores têm autorização para assumir contratos adicionais separadamente, para distribuição não exclusiva da versão do trabalho publicada neste periódico (ex.: publicar em repositório institucional, em site pessoal, publicar uma tradução, ou como capítulo de livro), com reconhecimento de autoria e publicação inicial neste periódico. Os editores da Revista têm o direito de proceder a ajustes textuais e de adequação às normas da publicação.

\section{PUBLISHER}

Universidade Federal de Mato Grosso. Programa de Pós-graduação em Educação em Ciências e Matemática (PPGECEM) da Rede Amazônica de Educação em Ciências e Matemática (REAMEC). Publicação no Portal de Periódicos UFMT. As ideias expressadas neste artigo são de responsabilidade de seus autores, não representando, necessariamente, a opinião dos editores ou da referida universidade.

\section{EDITOR}

Patrícia Rosinke (D) 9

\section{HISTÓRICO}

Submetido: 17 de agosto de 2021.

Aprovado: 08 de novembro de 2021.

Publicado: 27 de novembro de 2021. 